\title{
A Wave of Contemporary Insurgency in Balochistan
}

\author{
Muhammad Rizwan ${ }^{1}$, Muhammad Waqar², Muhammad Arshad ${ }^{3}$ \\ ${ }^{1,2,3}$ Department of Political Science, Hazara University, Mansehra, Pakistan
}

\begin{abstract}
Strategically positioned Balochistan, its colossal resources, and a very vast area have increased its significance in the global affairs. The external powers are taking immense interest in its massive resources, strategic location and most importantly being the most easily accessible pathway to the enormous resources of Central Asian States. It got more significance first, after soviet incursion of Afghanistan and second after US attack against Taliban in Afghanistan. From the very scratch, the misunderstanding emerged between the Pakistani State and Baloch people. The state alienation toward Balochistan has worsened the situation in province particularly regarding the economic and social benefits of Baloch people which resulted in blood uprising in the province. The insurgency has been the main hurdle in the utilization of its gigantic resources to benefit the populace of Pakistan and particularly the Baloch people. The discontinuity of the democratic process and the interruption by the military at regular intervals has aggravated the wounds of Baloch people more than the rest of its countrymen, especially during Musharraf regime. The contemporary insurgency is tougher and different than the previous ones in a sense that situation has changed globally and international actors are more fascinated by this vital part of South Asia.
\end{abstract}

Keywords: Balochistan, Contemporary, Insurgency, Strategic

\section{Introduction}

Balochistan is the Southern province of Pakistan, located in a very key position, connecting three countries namely Iran, Afghanistan and Pakistan. It expends over $347190 \mathrm{~km}$ which is about 43 per cent of the whole area of the country.[1] Balochistan is also attached to the other three provinces of Pakistan, in the East with Sindh, in the North-East with Punjab and in North with Khyber Pakhtunkhwa (formerly known as North West Frontier Province) through tribal area of South Waziristan. It is least populous state of Pakistan, consists of only 5 percent of Population of the country. Different ethnic groups reside in Balochistan including Balochi, Pashtun, Punjabis, and Sindhi etc. On the basis of 1998 census, Balochistan consists of 55 per cent ethnic Baloch (including Brahui), 30 per cent Pashtun, 3 per cent Punjabis, 2 per cent Saraiki population, and 1 percent of Urdu speaker.[2] The census does not differentiate between the Baloch and the Brahui people although they belong to different ethnic origins. Baloch populace are not only settled in Balochistan, but also in Sindh and Punjab.[3] It is also interesting to note that approximately 27 per cent of Baloch people live outside Balochistan, mainly in Sindh.

The history of Balochistan is full of bloody insurgencies. This insurgency was mostly because of confrontation between the Baloch masses and the federation of Pakistan from the very start. These relations were even bitterer following the exploitation of their resources and thus the ins and out in the relations with the federation of Pakistan continued.

From the very scratch, feeling of inferiority complex developed in the mind of Baloch people when the Pakistani authorities decided to compel the Khan of Kalat to accede to the new established state of Pakistan. For this purpose, in April, 1948, Pakistan Army moved into Kalat and compelled to sign the accession documents.[4] The people with the support of Khan's Brother Prince Abdul Karim Khan started rebellion against the state of Pakistan. But before that the Khan of Kalat and representatives of the government of Pakistan had reached an agreement on August 4, 1947. According to the agreement, the government of Pakistan accepted the independent status of Kalat state and had decided to take legal experts opinion on the issue. [5] But Pakistani authorities annexed Kalat state and thus the brother of Khan of Kalat prince Abdul Karim Khan started first uprising against the state security forces.[6] This insurgency started by the prince, lost its value and significance after his arrest.

The second insurgency was lead by Nawab Nouruz Khan Zarak Zai, against the amalgamation of Balochistan state Union with West Pakistan. This merger was developing sense of deprivation and neglectfulness in the Baloch people.[7] When the insurgency took more intensity, the government official decided to talk to the rebels, and declared that the demands and complaints of the Baloch masses will be sympathetically brought under consideration. But when the rebels came down the hills they were arrested by the security forces which included his close stalwarts and even his son. They were trailed in Haider Abad jail and 
sentenced to death. While Nouruz Khan death sentence was changed to life imprisonment due to his older age.[8]

The third uprising started in 1962. President Ayub Khan introduced new system of Basic democrats in 1960 and elected himself as president through these elected members. General election held in 1962, brought some Baloch nationalist to the front which the military dictator considered as danger to the basic democrats. So they were replaced by some nominated member from the central government with which a fresh spate of violence started. Sardar Attaullah Mengal was the first who challenged the writ of the government in 1964 and the regular encounter started between the Pakistani force and Parari's.[9] Another reason for worsening the situation was the establishment of military cantonment in Balochistan.[10] The nationalist leaders considered it as colonization of Balochistan and put their resistance against it. The rebellion ended after the Ayub Khan was replaced by General Yahya Khan in 1969. Yahya Khan ceased One Unit system on July 1, 1970 and Balochistan was given the status of province for the first time after 23 years.[11]

After the elections were held in 1970, Pakistan People Party (PPP) came out as a single largest party in West Pakistan. Following the debacle of Dhaka, PPP set up the government in West Pakistan. But in two provinces i.e. North West Frontier Province (now Khyber Pukhtunkhwa) and in Balochistan, National Awami Party set up their governments with the support of Jamait e Ulmai e Islam (JUI). The bitterness enhanced between the central and provincial government and at last the provincial government of Sardar Attaullah Mengal was dismissed in Balochistan and military action was started against the nationalist leader of Balochistan.[12] The prominent nationalist leaders were arrested and imprisoned. The nationalist stalwarts continued their struggle and stopped coal delivery to Punjab and some of the roads were also blocked. They also interrupted the exploration process in Balochistan.[13] The agitation continued until the General Zial Ul Haq coup and ousted Zulfiqar Ali Bhutto from government. Peace accord was made with insurgents and normalcy came to Balochistan after a very long lasted fight between the insurgents and military. The peace returned to the province adopting the old policy of reconciliation with the Sardar's. On January 1, 1978, the Chief Martial Law Administrator banned the Haiderabad Tribunal and announced the general pardon for all those who had fled from the country for being involved in uprising. He clearly stated that the closing of the tribunal was in the interest of the country.[14]

A peaceful environment prevailed in Balochistan for about twenty years from 1979-99. During this time, both the military and democratic government played their role to make Balochistan a nonviolent province and work for the betterment of the Baloch populace. The nationalist took parts in the various election held during this period.

\section{Balochistan During Musharaf Regime}

General Parvez Musharaf overthrew the civilian government of Nawaz Sharif and marshal was imposed in the country.[15] The Baloch people have always shown resentment and alienation with the military ruler, because of their direct confrontation with Baloch people in the previous insurgencies and that's why the uprising in Balochistan took more strength after a few years of Musharaf government. The events that triggered the violence in the province include the killing of Chinese engineer at Gwadar, murder of Nawab Akbar Bugti and the enforce disappearance and extra judicial killing of Baloch people. The volcano of Baloch eager erupted after the death of Nawab Akbar Bugti and an organised rebellion started.

Initially, the signs of guerrilla warfare started when in 2000 , the military cantonment were attacked regularly. The militant started attacking government building and other assents. The situation became more complex when Baloch People's Liberation Front accepted the responsibility of attacking the Levy Thana near Kohlu. Pamphlets were found in the nearby area inscribed with "Occupation of Baloch resources will not be tolerated".[16] As the violence continued and was spreading in the Baloch area, another organization came into being calling itself the Baloch Liberation Army (BLA) and admitted the responsibility of attacking the Frontier Constabulary. They forwarded the message that "they will fight against the fascistic Punjabis till victory and those responsible for the suffering of Baloch and Balochistan will be made accountable. The blood of Baloch spilt by Punjabis, its Army and their stooges will not be forgotten. May the soul of Baloch martyrs rest in peace".[17]

The Gwadar project was started in 2002 by the then president General Musharaf with a commitment to make Gwadar one of the major ports of the area.[18] China was the main contributor both physically and financially to construct this port. Chinese engineer was given the task to complete the project within the stipulated time. An unfortunate incident of car bombing occurred in the coastal town of Gwadar in 2004 killing 3 Chinese engineers on the spot and wounding others.[19] This menacing act of the terrorist was not only detrimental to the national outlook but also was to stop the economical development of Pakistan in general and Balochistan in particular. The killing of these engineers was traced back to the Marri militant.[20]

When the situation in Balochistan was aggravating and was going out of hand the then government decided to constitute a parliamentary committee on Balochistan to forward some recommendation and 
constitutional amendment to nationally integrate the Baloch people. Parliamentary committee with Choudary Shujaat Hussain as chairman was duly formed on September 29, 2004 to submit the comprehensive recommendation to the parliament within 90 days.[21] This committee was further bifurcated; one was chaired by Mushahid Hussain Syed and the other by Senator Waseem Sajjad. The committees were consisting of Baloch nationalist representatives such as Sanaullah Baloch belonging to Baloch National Party (BNP) Mengal group and Amanullah Kinrani of Jamhori Watan Party (JWP) of Nawab Akbar Bugti etc.[22] While expressing his view about the parliamentary committee on Balochistan, Nawab Akbar Bugti Said that "I am not very much sanguine about the effectiveness of the parliamentary committee, in the past such committees have been established but without any result. He reiterated that if government is willing to resolve the issue then a committee comprising of four or five members is enough to complete the task".[23] Similarly the BNP (M) also showed their dissatisfaction over the role of Parliamentary Committee and stated that the government is not serious in paying heed to the reservation of Baloch people. The people of Balochistan have not been taken into confidence on constructing Gwadar port. The exploitation of provincial assets, and the police of capturing the shore of Balochistan, is discriminatory act of the central government.[24]

The task given to the Mushahid Hussain committee was to look into the overall problem of Balochistan and address the reservation of Baloch people. While the other committee, chaired by Senator Waseem Sajjad was tasked to recommend some constitutional amendments. The former one completed his task while the later one did reach any consensus. Mushahid Hussain Syed committee in its different meetings held at Islamabad, Quetta and Gwadar from October 2004 to January 2005 thoroughly discussed the situation with the Baloch people.[25]

The committee recommended the following recommendations

1) The gas royalty will be paid to the Balochistan government and Balochistan will be given more representation in Pakistan Petroleum Limited (PPL), Oil and Gas Development Corporation Limited (OGDCL), and Sui Southern.

2) Quota system at the federal government ministries and division should be strictly followed.

3) The Gwadar Port Authority shall be immediately shifted from Karachi to Gwadar and 50 per cent representation will be given to Balochistan. With a package of 3 billion rupees, new educational institution will be established and infrastructure will be improved.

4) A network of National Highways will be spread all over Balochistan and the old one will be improved.

5) In order to improve living standard of the Balochistan people an anti drought strategy is going to be adopted, which will include the construction of dams.

Besides these main points the committee also showed concerns over the illegal detention of Baloch people and political workers. The committee admitted that law enforcement agencies are involve in cases of missing persons and it is necessary to solve this problem in order to move forward for the resolution of Balochistan issue.[26]

Besides this, the most ignited event that occurred was the rape of Dr. Shazia Khalid in the Sui area of Balochistan.[27] It was alleged that Captain Hammad of Defence security forces was involved in this menacing act. While leaving the country, she stated that "she does not know any one like Captain Hammad and had never heard this before this". She also appealed to the Baloch nationalist leader's especially Nawab Akbar Bugti to not politicise the issue.[28] But the blame game had started between the government and Akbar Bugti; Bugti was stressing that the captain of the security forces is involved in this shameful act while the government officials were repeatedly denying that there is no such involvement of security force officer. The tension increased day by day with the passage of time. The Bugti attitude now had and he was working more as nationalistic rather than to protect just the interest of his tribe. He was very much inflexible regarding the gas royalty, provincial autonomy and the most important, the constitutional rights of the province.

On March 17, 2005 the clashes between the insurgents and the military started in which ten 10 military personnel died and about 60 insurgents and civilian died.[29] The insurgents belonging to Baloch Liberation Army (BLA) started attacking the government installation. They were ambushing the military convoys and attacking other soft targets of military and important government machinery quite regularly. These actions of the rebels were increasing like the fire in a dense forest. Railway lines, Electricity installation, gas pipelines and other places were attacked by insurgents.

While the recommendations of the parliamentary committee was going to be finalised, an unfortunate incident happened when General Musharaf, the then president and Chief of Army Staff was going to address the local Jirga at Kohlu, a district of Balochistan, came under attack by the miscreants. [30] Following this, on December 15, 2005 the helicopter of the Inspector General, Frontier Corps (FC), was attacked injuring Major General Shujaat Zameer and Brig. Salim Nawaz. This attack by the militant was taken as challenging the writ of the government and they were warned about the stringent consequences. After these attacks on President Musharaf and IG Frontier Corps, Nawab Akbar Khan Bugti took to the mountains. 
As the violence continued, another grave attack on Chinese engineers occurred in 2006, in the Hub city of Balochistan. This regrettable incident took the lives of 3 Chinese engineers while they were returning to their homes in the nearby area. [31] The banned organization involved in insurgency and other anti state activities, Baloch liberation Army (BLA) took the responsibility of carrying out the bombing on Chinese engineers and stated that China should stop the entire projects in Balochistan. [32] The government of Pakistan expressed deep concern over this barbaric act of BLA and ordered the concern authorities to bring the perpetrator of this ominous act to justice. President Musharaf called it as "Blatant act of terrorism". [33]

The government considered Nawab Akbar Bugti as the main plotter behind all these inhuman terrorist attacks. So the military operation was initiated by the federal government against these insurgents in Dera Bugti. He was killed along with his stalwarts in the Bhambhore mount area on October 26, 2006. [34] Awais Ahmad Ghani, the then Governor of Balochistan told the media reporter's that Bugti died in the cave, when an explosion occurred in it. [35] It was also reported that about 16 personnel died during the operation including four officers. [36] He was laid to rest in Dera Bugti on September 1, 2006. The killing of the Nawab Akbar Bugti spread in the country like fire in the dense forest. He became the hero of Baloch nationalist's and insurgents. The way he fought the military, and he was widely appraised for his bravery and protest started all over the province.

The opponents of Bugti have always argued that he was constantly demanding for more royalty from the federal government with respect to the Sui gas field. But these entire allegations have not been proved. With his death, much doubt's raised in the mind of the common Baloch. Because when they see the situation like this that their leader are being kill in such brutal way, then how can they view themselves safe in their province. All parties conference was held in Quetta which widely condemned the killing of Nawab Akbar Bugti. [37] But from all this, one thing was very clear that the military was showing their iron hand to the entire nationalist leaders of country that, if they rear their head they will be dealt in the same way. [38] Another thing, which is very clear from this event, that now the problems are going to be solved through military operations rather than political dialogue. Due to this behaviour of the military ruler, the resentment increased day by day. The death of Bugti exacerbated the situation in Balochistan, attacks on the military and government installation increased, and the ethnic Punjabis were attacked.

Protests against the killing of Bugti were held in all over the country i.e. in Balochistan, Khyber Pukhtoonkhwa and Sind but no such protest was held in Punjab. The statement that came from some of the incumbents of Punjab, were very much irresponsible. The then Chief Minister of Punjab Choudhary Parvez Elahi said that "we support Musharaf in his action to establish writ of the government". The Governor Punjab, Mr. Khalid Maqbool went step ahead of the Chief Minister and said "the nation salute to the President Musharaf for eliminating those individuals who were impeding the developmental projects in Balochistan". [39] Such types of statements were to increase the gulf between the two ethnic groups and thus the hatred develop to such an extent that bearing each other ethnic groups became difficult. The Baloch has always been considering the Pakistan army as Punjabi army because of their representation. In a joint press conference with Mian Muhammad Nawaz in Karachi, the veteran Baloch leader Mr. Attaullah Khan Mengal sharply criticised Pakistan Army and said that "it's not Pak Army, but its Punjabi Army who are involved in human rights violation and there is no point of return for the Baloch people"..[40]

The killing of Balach Marri, [41] who was allegedly involve in different terrorist attack on government machinery also deteriorated the situation. He was considered to be the leader of Baloch Liberation Army (BLA), an anti state organization involved in various terrorist attacks in the province. It was said officially that Balach Marri has been killed somewhere in Afghanistan while his family member said that he was killed during fighting with the security forces. [42] After this some unknown mobs attacked the policemen in Quetta killing two of them, three other people were also killed in Kalat streets while government offices, vehicles and some shops were also set ablaze. His brother, Habiyar Marri was apprehended along with an aide by Scotland Yard on December 6, 2007. [43] Later he was released on bail. After coming to power, the Pakistan People Party (PPP) withdrew all the cases against Harbiyar Marri and his father Khair Bakhsh Marri. [44] But the situation remained the same and violence continued in the entire province.

It is clear that during the Musharaf regime from 1999-2008, the insurgency was growing day by day. But along this, some mega projects were also initiated in the province for the betterment and welfare of the people of Balochistan such as Gwadar port, Saindak project, Kachi Kanal, Mirani Dam and some important Highways. Gwadar port construction is one of the mega projects ever started in the province since independence. The inauguration of Gwadar port first phase in 2002 and its completion in 2007 was a milestone achieved toward the economic development of the province. The strategically located Gwadar port is just $72 \mathrm{~km}$ away from Iranian border and situated at the opening of the Strait of Hormuz. [45] Besides the Gwadar port construction, some others projects were also instigated by the Musharaf government, Such as Kachi Canal, Mirani Dam, Saindak and Riko Diq project, and spreading a network of roads in the province. President Musharaf reiterated his commitment that "the aim behind these projects is to improve the living standard of the 
people of Balochistan and bring more prosperity and development to the region". [46] despite all these efforts by the Musharaf government to bring the Baloch people in national circle and improve their living standard, the Musharaf government from 1999-2008 is considered to be the darkest age for the Baloch people because their plights increased due to insurgency and oppressive military action, until he stepped down in 2008. The insurgency remained at high scale during his power.

\section{Balochistan During Pakistan People Party Government}

The election held in 2008, brought Pakistan People Party (PPP) to rule the country. [47] Soon after that, Asif Ali Zardari was elected as President of Pakistan on September 6, 2008. [48] He extended his apology to the people of Balochistan on behalf of the whole nation and assured them that concrete measure will be taken for the betterment of the Baloch people. Though nationalist power had not taken part in the 2008 election due the killing of Nawab Akbar Bugti, the PPP government strived to reinstate the trust of the common people.

In November 2008, the government of Pakistan People Party decided to grant more autonomy to the provinces. In order to remove the grievances of Baloch people, the government presented a 39 points plan in the parliament on November 24, 2008 called "Aghaz e Huqooq Balochistan". [49] The content of this package included the return of exiled political leaders and withdrawal of cases against them, the release of the political workers, the pulling out of the army from some areas, changing the criteria of federal resources distribution, creation of jobs for Baloch youth, and more provincial autonomy on its natural resources. The parliament approved it in December 2009. [50]

Similarly, the other milestone achieve during the same government was the distribution of resources among the federation and provinces and also between the federating units through National Finance Commission (NFC) award. Before the $7^{\text {th }}$ NFC award, the only criteria for the allocation of resources was based on population, but in the seventh NFC award the criteria was changed and was based on population with $82 \%$ weight, revenue $5 \%$, backwardness $10 \%$ and inverse population density was given $2.7 \%$ weight. This increased the share of the provinces due to the more opening of divisible pool. The vertical distribution i.e. between Federal and Provinces enhanced form 47 per cent to 56 per cent for the year 2010-11 and 57 for the remaining years, which also increased the horizontal distribution i.e. between the provinces. With these allocations and changes in criteria, the Balochistan was enable to secure 9.09 per cent share in the divisible pool. President Asif Ali Zardari formally signed the NFC award on Tuesday, March 16, 2010. [51] The other step toward the elimination of the deprivation of the province was taken to bring $18^{\text {th }}$ amendment bill to the parliament.[52] Through this bill, the provinces were given more autonomy and several ministries were transferred to provinces to abolish the concurrent list.

Besides all these developments, which were carried out to strengthen the federation and empower its units, could not change the situation as it should have been. The nationalist elements and insurgents envisaged these packages and concession as deception and a continuation of policies of General Musharaf. The vital thing is that the provincial Chief Minister and other political leaders who were the part of that time government showed ambivalent attitude regarding these developments. However, all were striving hard for the confidence building measures to persuade the insurgents toward reconciliation. [53] The insurgent attacks and religious extremists enhanced after 2006. Approximately 3387 such attacks have claimed 2,164 lives and injured 4,411 people in Balochistan in five years, from January 2007 to December 2011. [54] The killing of three nationalist leaders belonging to Balochistan nationalist parties aggravated the situation. The violence paralyzed the normal life in Khuzdar, Turbat, Quetta and other areas. These leaders were named as Lala Munir Baloch of Balochi National Front (BNF), Ghulam Mohammad Baloch of Balochi National Movement (BNM) and Sher Muhammad Bugti of Baloch Republican Party (BRP). [55]

\section{Enforced Disappearance And Extra Judicial Killing}

Extra Judicial killing and enforced disappearance in Balochistan is a dilemma developing a sense of insecurity in the common Baloch people. This issue has been at the top of the list of all the problems. The intelligence and law enforcement agencies have been accused in this menace act, in order to control and suppress insurgency in the province. While the problem is widespread, the exact statistics of these enforced disappeared people is unknown, however, different organizations presents different statistics which vary greatly. [56] The nationalist figure is far different than that of government.

Human Rights Commission of Pakistan (HRCP) says that they have received complaints of 600 missing persons. Out of which, 240 have been verified, and 40 person have been killed. [57] Human Rights Watch in Pakistan in its reports stated that there is a massive human rights violation in Balochistan. According to their statistics many people have been picked up by the security agencies and there have been no clue of these people so far. Most of the peoples belong to the nationalist parties that has been arrested and disappeared. Such as Baloch Republican Party (BRP), Baloch National Front (BNF), Baloch National Movement (BNM), Baloch Student Organization (BSO) and Balochistan National Party (BNP). There are some evidences also that people 
have been picked up by the security agencies regarding their tribal affiliation. [58] The Inspector General Frontier Corps, Ubaidullah Khan Khattak, categorically rejected the Human Rights Watch (HRW) report about the disappearance of Baloch people by the security agencies and Frontier Corps and said that "such types of reports are to encourage the insurgents and discourage the law enforcement agencies". [59]

The provincial interior minister Mr. Zafrullah Zehri in January 2011, told in the provincial assembly said that "only 55 people are missing in the province". [60] The interior minister Rehman Malik in his address to the senate about the situation in Balochistan told that "there are 2390 cases of abduction, in which the address of 135 persons were incomplete, 241 persons particular were incorrect while 36 were working in the Middle East". He further stated that "we scrutinized every case and found only 32 persons in jail, now there are 36 cases of missing persons in Balochistan". [61]

The Chief Justice of Pakistan has taken a sue motto action about the law and order situation in Balochistan and also about the dilemma of missing persons in the province. Hearing the cases, he strongly criticised those who are responsible in deteriorating the situation in the province. The apex court comprising of Chief Justice Iftikhar Muhammad Choudhary, Justice Jawwad S Khwaja, Justice Sheikh Azmat Saeed, after hearing the case at Quetta, the Chief Justice Iftikhar Muhammad Choudhary stated "we order the government and FC to recover the missing person as quickly as possible. We order the all agencies to guarantee the safety of the lives and properties of the people under Article 9 of the constitution". He further said that "there is proof about the FC but no person has been produced so for". "Don't enforce us to pass an order" he added. [62]

The situation in Balochistan is so severe that the civil officers are denying their duties in Balochistan. They envisage that they will not be able to protect their lives due to increasing insurgency in the province. The situation is so aggravated that abduction for ransom and target killing is a daily routine. The chief secretary Balochistan told the court that the civil officers are repudiating their duties in the province. Upon this, the court ordered to take the written statement from the officer if they are denying their duties in the province. [63] Many times the court has reminded the federal and provincial governments to take stern action against those violating the law, to protect the basic rights of the people.

\section{Contemporary Insurgency And External Involvement}

The day by day deteriorating situation in Balochistan is the evidence of the external involvement in the province. The way in which the insurgents are attacking the military installations and government offices, bombing the military conveys and post, such attacks cannot be carried out without proper training and planning. It is estimated that the daily expenses of the militants are in millions. The spying agencies of Pakistan estimate that the one month expenses of Baloch Liberation Army are estimated to be Forty to Ninety Millions. [64] The enemies of Pakistan have the desire to weaken the state by igniting the insurgency. The colossal resources and the strategic position of Balochistan attract them immensely. The aspiration of the powers is that the resources should be exploited by the independent Balochistan rather than by the state of Pakistan. [65] These external powers are interested to have some part in Balochistan gigantic mineral deposits and take advantage of its location. The other fact is that the militant have easy access to the most sophisticated weapons which they are used against the law and enforcement agencies, is apparent sign of external support to them.

Who could be those powers involved in Balochistan? According Dr. Ayesha Siddiqua, fellow at the Woodrow Wilson International Centre, Washington, these external powers could possibly be India, Iran and Afghanistan. There is also engagement of the American agencies working in Balochistan. [66] These involvements in Balochistan are based on the interest of these powers. The age old antagonism between India and Pakistan is not concealed from any one. The too much engagement of India in Afghanistan affairs to provide assistance in the military and economic sectors is a matter of concern for Pakistan. According to the officials in Pakistan, the presence of Indian consulates in the area of Pak-Afghan border and also in Zahidan is encouraging and it is used as base camp for the insurgent movements. [67] The development of Gwadar port is hampering the interests of both the India and Iran. The Chabahar port jointly developed is losing its importance with the emergence of Gwadar port. India has spent millions of Dollars to develop this port. Recently, the Indian economic experts visited Tehran, to invest in the Chabahar port in order to compete with Gwadar developed with the Chinese support. [68] The successful development of Gwadar port can also be the point of concern for the Iranian authorities. The Russian involvement cannot be denied. The Russian arrival in Afghanistan and then its humiliating departure, considers Pakistan responsible for its defeat. There are also claim by the Russian that Pakistan is supporting the Chechen rebels. On the other hand, the Baloch insurgent are using Russian made weapons. So these allegation and possession of Russian weapons with insurgents increase the concern of Pakistan.

The relations between Pakistan and Afghanistan remained tense from the very scratch because of the issue of Pukhtunistan. Afghanistan envisages that Pakistan is responsible for the disturbance in Afghanistan and is supporting Taliban. Many times the Pakistani authorities have complained about the presence of Brahamdagh Bugti in Afghanistan and his camps from where he is operating in the restive province. During the meeting 
between the Pakistani president Asif Ali Zardari and Afghan president Hamid Karzai in September 2010, the issued was raised by interior minister Rehman Malik. Asking his counterpart to abandon those camps headed by Brahamdagh Bugti, the man responsible for disturbance in Balochistan. [69] Brahamdagh Bugti is running camps in the Kandhar province of Afghanistan, in which he was training round about 4000 to 5000 militants, said Rehman Malik. But upon the insistence of the Pakistan authorities, the Afghan government has compelled Bugti to leave Afghanistan and therefore, he took political asylum in Switzerland. He added that Hamid Karzai admitted that the militants from Afghanistan were creating problems in Balochistan. [70]

Some reports are also there about the American involvement in Balochistan, although Pakistan is their front line ally in the war against terrorism. The leading news paper, The Herald, says that America is supporting Baloch insurgents in order to cope the Chinese influence in Balochistan. [71] It is also believed that the main source of financial support to the insurgents comes from the CIA agents in Afghanistan. [72] The basic aim is to put a damper on increasing Chinese existence in Balochistan. The USA sees China as their arch rival and its presence in Balochistan is puzzling them for the future. The Gwadar port can be the naval base for Chinese forces in future which is a matter of great concern for USA. The Chinese presence in the Indian Ocean, near the Strait of Hormuz, which is busiest route for the export of oil from the Gulf States, will be under the observation and influence of China. While the USA, wants to maintain its monopoly in the region. This conflict of interest is also deteriorating the situation in Balochistan. As far as the situation in Balochistan remains unstable, the Chinese authority will be compelled to have a second look at their growing economic assistant to Pakistan. [73] The US interest in region is not restricted to Balochistan alone, but have eyes on the colossal resources of Central Asian States and Balochistan is the most easily accessible path to these resources. US would like to have control on the region for their future plans and eradicate China from the scene which is their only competitor in the region.

\section{Conclusion}

The contemporary insurgency in Balochistan is the output of the mistrust between the government and the Baloch people. The uprising at regular intervals is the production of marginalization and economic exploitation of their resources. The inconsistency of political process in the country has exacerbated the situation more. When the political governments, are over thrown and replaced by the military dictators, the decision are taken without any consultations, which exasperate the situation. Same happened when General Parvez Musharaf was implementing his orders and was giving no weight age to the political negotiations. He in fact threatened the nationalist leaders in Balochistan while giving interview to a private television channel Geo, on February 10, 2005 and said, "Don't push us... it is not 1970s, this time you will not even know what has hit you."

The situation in Balochistan is very complex and day by day it is worsening. There is no sign of government rule in the province. The target killing, kidnapping for ransom, enforced disappearance, explosions, sectarian violence and attacks on the government installations is happening in usual. The capital city, Quetta has been the main target. The situation is so dangerous that the province is moving toward anarchy. The people are not safe in their homes. The sectarian violence in Balochistan has increased in the recent time. The attacks on the Shai community in Quetta which killed at least 89 peoples leaved the city with grief. [74] Same types of attacks have been occurred many times and occurring at regular intervals. This attack on the Shai sect is considered to be the most dangerous attack causing many deaths and leaving many people injured.

The present insurgency in Balochistan is the output of mistrust among the political forces and the insurgents. The political forces who want to solve the problems through peaceful means i.e. through negotiation with in the constitution of Pakistan. On the other hand, the insurgents believe in the violence. They want to solve the problem by force through unconstitutional means. Political will is required to bridge the gulf between the insurgents and government. Make them sure that their rights will be delivered to them under the constitution and they will be given more opportunity to improve their living standard.

There should be no role of the intelligence agency in the political affair of the province, so that the political forces should make their own decisions in a political domain. The role of agencies must be restricted to the law and order situation and other safety measures. In Balochistan particularly, their role is increasing day by day. The nationalists have always complained about this increasing influence of the agencies. Sardar Akhtar Mengal arrived to Pakistan after the self imposed exile and presented his six points in the Supreme Court of Pakistan in which he criticised the role of agencies in the province. [75]

The extra judicial and enforced disappearance in the province is the most volatile issue needed to be resolved wisely. This menacing practice should be stopped as it is enhancing the mistrust of the people on the security agencies and enhance the hatred with the state. Anyone involved in the charges should be produced in the court to face and defend his charges. If he is found guilty should be punished. This will improve the image of the security agencies and reinstate the trust of the masses. 
Another equally important thing is to enhance the participation of Baloch people in every walk of the life. Provide them the opportunity to settle down their own problems. The ongoing mega projects in the province should have opportunities for the Baloch people. The main concern of the Baloch people is that their ethnic dominance is decreasing and according to their estimate one day, they will become minority in their own province which is a point of concern for them. The social structure of Balochistan is continued to be based on the tribalism. [76] Let them decide their own faith but provide them with more education. The more educated Baloch will play a constructive role in the development of Balochistan in particular and Pakistan in general. There is a need to take prudent actions to resolve the Balochistan issue, otherwise it is going on the wrong side i.e. anarchy and disturbance. The external power will take the opportunity to use it against the state of Pakistan. The Baloch nationalists are required to be taken in confidence to resolve this burning issue amicably.

\section{References}

[1] Pak Institute of Peace Studies, Conflict and Insecurity in Balochistan (Islamabad: Narratives Pvt Ltd, 2012 ), p 13.

[2] Last census was held in 1998 and now the population of the country has increased, but it is the only reliable source for different statistics.

[3] Muhammad Sardar Khan Baluch , History of Baluch Race and Baluchistan (Quetta: Nisa Traders, 1958).

[4] Muhammad Asghar Khan, , General in Politics: Pakistan 1958-82 (London: Croom Helm, 1983 ), p 177.

[5] Ahmad Yar Khan Baloch, , Inside Balochistan (Karachi: Noor e Rehman press, 1975), p 154

[6] Owen Bennett Jones, , Pakistan: Eye of the storm (New Haven: Yale University Press, 2002) p.133.

[7] M.M.S Dehwar,., Contemporary History of Balochistan, (Quetta: Third World Publication, 1994) p 340.

[8] Selig S. Harrison, In Afghanistan's Shadow: Baluch Nationalism and SovietTemptations (New York: Carnegie Endowment, 1981), p. 28.

[9] Muhammad Azhar Khwaja, "Killing American style", The Nation, Lahore, September 7, 2006.

[10] Justin S Dunne, Crisis in Baluchistan: a historical analysis of the Baloch nationalist Movement in Pakistan, master thesis, naval Postgraduate School Monterey, California, 2006

Daily Jang (Urdu), Karachi, July 2, 1970.

White Paper on Balochistan, (Rawalpindi: Government of Pakistan , 1974)

Awan, A. B., Baluchistan: Historical and Political Processes (London: New Century Publishers, 1985), pp. 227-33.

Ibid., p 302.

[15] General Musharaf was the fourth general who toppled the civil government of Nawaz Sharif on October 12 , 1999 with a commitment to bring real democracy to the country.

[16] Mushir Anwar, Balochistan: Rationalization of Central-Province Relations (Islamabad: Islamabad Policy Research Institute, 2010), p 103

Ibid., p 104.

Daily Dawn, March 23, 2002.

Daily The News, May 5, 2004

Daily Times, Monday September 4, 2006

Daily Dawn, September 30, 2004

Ibid.

Daily Dawn (internet edition), Friday, October 1, 2004

Daily Dawn, Saturday, December 18, 2004

Report of Parliamentary Committee on Balochistan, November, 2005

Ibid.

Dr. Shazia was working as Medical practitioner with Pakistan Petroleum Limited at Sui near Dera Bugti. She was raped by unknown persons between the night of 2 and 3 January, 2006.

Daily Times, Saturday March 15, 2005

Daily The News, Saturday, March 19, 2005

Daily Times, Tuesday, December 20, 2005

Daily Times, Thursday, February 16, 2006

Ibid.

Ibid.

Daily Times, Lahore, August 27, 2006

Nadeem Syed, "Lacklustre opposition", The Nation, Lahore, September 4, 2006.

Ibid.

Daily Dawn, September 4, 2006

Laif, M. Ejaz and Hamza, M. Amir, Ethnic Nationalism in Pakistan: A Case Study of Baloch Nationalism during Musharraf Regime, Pakistan Vision, Vol. 10, 2002, 49-81.

[39] M Ishaque Fani, Surriya Shahab, Muhammad Nadeem, et al, The Resurgence of Baluch Ethnicity and

Nationalism in Baluchistan, European Journal of Social Sciences - Volume 20(4), 2011, 656-676.

[40] Daily Dawn, Friday, December 20, 2011.

[41] Balach Marri was the youngest son of Khair Bakhsh Marri, the veteran Baloch Nationalist. He was killed on November $21,2007$.

[42] Daily Dawn, Thursday, November 22, 2007.

[43] The Post, Islamabad, December 27, 2007.

[44] Weekly Akhbar-e-Jahan (Urdu), Karach, October 13-19, 2008.

[45] Syed Fazal e Haider, "the Potential of Gwadar Port", Dawn, Friday, August 3, 2012.

[46] President Musharaf was speaking at the inaugural ceremony of the first phase of the Gwadar port. He mentioned that the economic uplift Baloch people is important to bring prosperity in the country.

[47] This was the ninth general election in the history of Pakistan held on February 18, 2008 for the total of 272 general seats. Pakistan People Party secured 97 seats and emerged as leading party.

[48] Daily Jung, Sunday, September 7, 2008.

[49] Daily Times, Wednesday, November 25, 2008 
[50] For a detailed analysis of the package, see The Aghaz-e-Huqooq-e-Balochistan Package: An Analysis (Islamabad: Pakistan Institute of Legislative Development and Transparency, 2009).

[51] Daily The News, Wednesday, March 17, 2010.

[52] $18^{\text {th }}$ amendment is considered to be the milestone achieved to the provincial autonomy which was approved from the parliament on April 15, 2010

[53] Pak Institute of Peace Studies, Conflict and Insecurity in Balochistan, (Islamabad: Narratives Pvt Ltd, 2012 ), p 13.

[54] Ibid.

[55] Who killed the Baloch leaders?, Daily Dawn, Friday, April 10, 2009

[56] Balochistan: Conflict and Players, (Islamabad, Pakistan Institute of Peace Studies, 2008), p 114.

[57] Pushed to the wall: a fact finding mission report on Balochistan, (Lahore: Human Rights Commission of Pakistan, 2009$)$, $\mathrm{p} 13$.

[58] "We can torture, Kill, or keep you for years” Enforced Disappearances by Pakistan Security Forces in Balochistan, (New York: Human Rights Watch, 2011), p 3.

[59] "No enforced disappearance in Balochistan: IGFC", Daily Times, Thursday, August 25, 2011.

[60] Pak Institute of Peace Studies, Conflict and Insecurity in Balochistan (Islamabad: Narratives Pvt Ltd, 2012$), \mathrm{p} 114$.

[61] The Express Tribune, August 4, 2012.

[62] The Lahore Times, October 9, 2012

[63] Daily Times, Wednesday, September 18, 2013

[64] Muhammad Ilyas Khan, 'Back to the Hills'. The Herald, Karachi, September 2004.

[65] Shafqat Mahmood, 'Centre does not hold', The International News Internet Edition, January 21, 2005

[66] Dr Ayesha Siddiqa, 'The Cost of Conflict in Balochistan', The Friday Times, January 2005.

[67] Shireen Mazari, "Balochistan and the "Great Power Games"'. The International News, February 2, 2005,

[68] Tehran Times, Sunday, June 2, 2013.

[69] Daily Times, "Pakistan seeks action against Brahamdagh Bugti", Thursday, September 16, 2010.

[70] The Express Tribune, March 15, 2012.

[71] Muhammad Ilyas Khan, 'Back to the Hills'. The Herald, Karachi, September 2004.

[72] Alok Bansali, Factors leading to Insurgency in Balochistan, Small Wars \& Insurgencies, Vol. 19(2), 2008, 182-200.

[73] Shireen Mazari, "Balochistan and the "Great Power Games". The International News, February 2, 2005,

[74] Daily Dawn, Sunday, February 17, 2013

[75] The Express Tribune, September 28, 2012

[76] Nadeem Qasir, Pakistan Studies: An Investigation into the Political Economy 1948-1988, (Karachi: Oxford University Press, 1991), p 26. 